\title{
3 Violence against strikers in the rural peripheries of the Iberian Peninsula, 1890-1915*
}

\author{
Assumpta Castillo Cañiz
}

\section{New repertoires of protest in a changing rural space}

In October 1903, the Spanish conservative newspaper La Época noted the alarm created by the "large number of workers" in the mining area of Bizkaia who were participating in the so-called Bilbao strike. According to the newspaper, this type of protest made a greater impression in Spain than in other countries where the higher level of industrial development meant that strikes were more widespread and frequent, and that therefore the authorities and society there were somehow more used to them. ${ }^{1}$ In fact, La Época was right to be concerned, as strikes were on the rise in Spain, especially in contexts and sectors other than the traditional industrial ones. The same went for Portugal. Even though neither Spain nor Portugal were paradigmatic cases of social conflict during this period (the number of strikes remained comparatively low in both countries), we can see a relative upward trend in the use of strike action as an effective tactic in the collective struggle, a pattern that becomes very evident from 1909 onwards. ${ }^{2}$ Furthermore, the levels of intensity of these strikes, measured by the number of participants and the degree of confrontation with public forces, were, on the whole, significantly high. ${ }^{3}$ In both countries, the numerical weight of the strikes was concentrated in the main cities and their surroundings: Barcelona and Madrid, in Spain; Lisbon and Porto, in Portugal. ${ }^{4}$ Nonetheless, in both cases the data show a gradual territorial extension of strikes. In Spain at the beginning of the twentieth century, the number of strikers began to rise even higher in other provinces where there was significant industrial activity, particularly in the mining and public works sectors. ${ }^{5}$ In Portugal, we see Lisbon and Porto beginning to be overtaken in terms of the number of strikes by other centres where economic activities were closely linked to the primary sector, whose workers were particularly active in the years around the turn of the century. ${ }^{6}$ In Spain, according to the fragmentary available data, the sector where strikes grew most exponentially throughout the period was agriculture (particularly from 1912 onwards). Agricultural strikes would have particular importance in Portugal from the beginning of the republican regime among the workers of the Alentejo. During these years, furthermore, areas traditionally associated with agricultural work saw this activity give way to the growth of other economic activities and new strategies of struggle, as had already occurred in the mining area of Baixo Alentejo in the last decades of the nineteenth century. ${ }^{7}$ 
This chapter examines the nature of violence against strikers in three different episodes that took place in the rural peripheries of Spain and Portugal over the last decade of the nineteenth century and the years preceding WWI. First, it examines the strike movements during the last decade of the nineteenth century and, in particular, the first two decades of the twentieth in the east of the Spanish province of Huesca (Aragon), an area particularly affected by the acute agricultural crisis. ${ }^{8}$ The protests here were led by rural workers who were seasonally engaged in the construction of public works, namely railways, roads and water supplies, and in the energy industry. Second, it examines the strikes by rural workers that took place in 1901-2 in the Spanish province of Badajoz (Extremadura). In this area of large landowners, the turn-of-the-century crisis led to a process of cereal specialisation and expansion of the traditional model of extensive agriculture. The short-term benefit of this specialisation triggered the concentration of the proletarian population in medium-sized cities. Third, it reviews the cycle of strikes that took place at the beginning of the Portuguese Republic in the region of the Alentejo (1911-15), where cereal specialisation went hand in hand with technical and social advances. Here, economic activity was gradually diversified, the capitalist agricultural model became a pole of attraction for the working population and some industrial nuclei were created. ${ }^{9}$

Regional differences in the socio-economic transformation were accompanied by differences in the degree and pace of politicisation. In both Spain and Portugal, the countryside gradually entered the political space, especially through the extension of suffrage and union rights. However, Spanish laws on association (1887), male suffrage (1890), agricultural unionisation (1906) and strikes (1909), and Portuguese laws on agricultural unionisation (1894), association without previous authorisation (1907) and strikes (December 1910) had limited impact on the countryside and did not change the authorities' attitude to a fully implemented democratisation. In fact, these measures went hand in hand with the reinforcement of repressive mechanisms. As in other European countries, exceptional laws were enacted in the last decade of the nineteenth century (in Spain the repressive laws on terrorism, 1894, 1896; in Portugal the law on the repression of anarchism, 1896). However, what was most instrumental in unleashing the repressive potential of both states, particularly in the case of Spain and increasingly in the case of Portugal (especially from the beginning of the Republican regime in 1910), was their view that socio-labour conflicts, and even the rise of workers' associations, were challenges to public order that had to be occasionally repressed. ${ }^{10}$ In all three cases, the repression of strikers was delegated to four different forces: the army, as the ultimate guarantor of so-called "public order"; the gendarmeries of each country, the Spanish Civil Guard (Guardia Civil) and the recently created Portuguese Republican National Guard (Guarda Nacional Republicana); local security forces, clearly insufficient in view of the scale and nature of these conflicts; and private forces or civilian volunteer corps, which in both countries played an important role in defending the interests of property.

The strengthening of private mechanisms for the preservation of order went hand in hand with an upward trend in employer associationism. Although this 
coincided with a radicalisation of positions, it was based on habitual practices of private control in areas where the political costs of repression had traditionally been lower. The exercising of the right to strike aroused new fears, even more so when, as was often the case, it was related to the penetration of new political tendencies.

Although historiography has delved into the nature of repression and police deployment in both Spain and Portugal, ${ }^{11}$ work remains to be done, especially with regard to the interplay between the centre and the rural periphery, and between the public and private spheres in the policing of protests. The same goes for the specific practice of strikebreaking, which provides a lens through which we can shed new light on the use of violence during this period and how the elites and the state managed the challenges posed by the new mass politics. ${ }^{12}$ In the three cases discussed in this chapter, the emergence and the nature of these strikes and how and by whom they were repressed are issues that must be assessed under the prism of belonging to a "double periphery": with respect to the most dynamic spaces of capitalism at the global level, and with respect to the decision-making centres within their respective territories. ${ }^{13}$ These are also defining issues for many other regions and areas worldwide, hence the significance of the present contribution in this collective volume.

\section{Tension in public order mechanisms}

In 1890, the Spanish Prime Minister, Antonio Cánovas del Castillo, stated that the army was a "robust support for social order and an invincible dam against the illegal attempts of the proletariat". ${ }^{14}$ Definitive consolidation of the process of militarisation of the public order system in Spain can be found a little more than a decade earlier with the enactment of the law constituting the army (1878). It stated that the task of the body was to act against the enemies of the fatherland, both external and "internal". In Portugal, too, the army was the main police force throughout the period, a role anticipated in the mid-nineteenth century. Although the control of public order was militarised to a far lesser degree than in Spain, this began to change with the inception of the Republican regime. ${ }^{15}$ In 1911, the National Republican Guard was created in Portugal, which until then had been the only continental country without a gendarmerie. ${ }^{16}$ The Spanish Civil Guard and the Portuguese National Republican Guard together with the army were the cornerstone of the repression of strikes in both countries. However, behind the territorial deployment of both bodies was not only the need to preserve or restore public order, but also the latent idea of a social upheaval following any kind of collective demonstration and certainly a work stoppage. ${ }^{17}$ Although these episodes were usually of brief duration or the conflict was resolved through mediation between workers, authorities and employers or construction managers, the threat of force as a deterrent was on the table from the beginning.

In both Spain and Portugal, the public order model had been strengthened and adapted to meet new needs, but there were some elements that occasionally, and increasingly frequently, put pressure on both systems: the growing supra-local 
nature of conflicts, their actual or potential territorial extension, and their increasing simultaneity. Although these were not entirely new elements, their interaction with a more politicised context significantly changed how they were perceived and experienced.

The misgivings of the Portuguese and Spanish elites and authorities multiplied in the face of an increasingly recurrent scenario: the concentration of workers in particular areas of both countries, especially where public works were being constructed and where public or private economic activity generated a significant need for labour. In some areas, workers were gathered in their hundreds, often outside the cities, as was the case at the turn of the century during construction of the Canal of Aragon and Catalonia in the east of the province of Huesca and in the Catalan province of Lleida. In 1897, shortly after the state took over construction of the infrastructure, there were increasing concentrations of labourers demanding work on sites that were progressing only intermittently and not absorbing the anticipated workforce. Up to 3,000 workers were making such demands in towns of not even a thousand inhabitants. This was the case in San Esteban de Litera, where in mid-March a partial strike was declared. April saw a concentration of workers not only from the town itself, but also from the region's capital, Tamarite, and other neighbouring towns. ${ }^{18}$ The supra-local nature of the protest was revealed as being of paramount importance. This is made explicit, for example, in the increasingly frequent communications between the Guardia Civil commands of the Canal construction zone in Huesca and the Ministry of War in dealing with the strikes of 1901 and 1903 in the towns of the Canal area, conflicts which would worsen in the following two years. ${ }^{19}$ In Extremadura, the general strike of agricultural workers and stockbreeders, as well as domestic servants called by the workers' association of the city of Badajoz in May 1901 was taken up by neighbouring towns, a situation that would be repeated in 1902 with a new general strike of agricultural workers throughout the province. ${ }^{20}$ In the Portuguese region of the Alentejo, the number of municipalities in which rural workers went on strike during the summer of 1911, mainly in the district of Évora and some areas of Portalegre and Beja, rose to 27 in just one and a half months. ${ }^{21}$ The provincial city was the driving force and at the same time the recipient of a large number of these demands for work, sometimes with a dynamic that some called "invasion of the city". In March 1912, the Portuguese government took steps to investigate the events that had taken place during the two waves of strikes by the Alentejo's rural workers, in the summer of 1911 and in January 1912, whose epicentre was the city of Évora. As some owners told the government's delegated commission, in January "herds of people [magotes de povo] from the countryside" had begun to enter the city. Some newspapers would also describe this episode as an "assault on the city", an expression not far removed from the one the governor himself would use, pointing out that, despite the efforts made, the workers "gradually invaded the city". ${ }^{22}$ Some local newspapers spoke of more than 15,000 strikers, of whom more than 10,000 would have come along the Reguengos de Monsaraz road, which became the most heavily guarded thoroughfare during this second phase of strikes, with the 5 th Cavalry Regiment being sent there. ${ }^{23}$ 
Along with this, a second key element was gaining importance: the extension of the protest to new territories and involving workers from various company branches or other production areas. This was the case with the numerous works that were being carried out in the Pyrenees and Pre-Pyrenees in Catalonia and Aragon at the beginning of the century for the construction of hydroelectric power stations. It was not unusual for groups of workers to travel seasonally from one centre to another in search of work, despite belonging to different companies, as they were not very far from each other. In June 1913, more than 2,000 workers left their jobs at the Energía Eléctrica de Cataluña's construction site in Capdella in the Catalan region of Pallars on the border with Aragon. ${ }^{24}$ In December of the same year, the construction workers of another hydroelectric company, Barcelona Traction Light and Power, better known as "La Canadenca", had done the same in Aitona, another border town, when the company refused to approve the workers' demands. ${ }^{25}$ In May 1914, 350 workers at the Compañia Catalana de Gas $y$ Electricidad's construction sites of the Seira and El Run hydroelectric power plants in the Ribagorza region of Huesca also determined to demand a pay raise. ${ }^{26}$ In the context of a broader articulation of the labour movement, this extension of the protest was manifested in another way: a call for solidarity strikes. After the repression of the Évora rural workers' strike in January 1912, which resulted in one death and several serious injuries, a general strike was declared and was widely supported in several parts of Portugal, including the capital. The strikes in the mining area of Baixo Alentejo were also part of this dynamic of general protest. In Lisbon, a state of siege was declared and the city was handed over to the military authorities, an unprecedented event. ${ }^{27}$ Previously practically isolated nuclei being drawn into cycles of conflict that affected the whole country was a new threat, something that the Spanish authorities could not fail to notice in cases such as Badajoz in 1902. Underlying this extension of the protest was another element that particularly concerned the authorities: political and union propaganda. In the province of Badajoz, territorial articulation of the labour movement became very evident when, after the initial strike episodes in 1901, the first regional workers' meetings began taking place. At the end of April 1902, the first workers' congress was held in the town of Torre de Miguel Sesmero, some 30 kilometres from Badajoz, and was attended by delegates from 21 towns representing more than 14,000 workers. Two months later, the convening power of provincial trade unionism became very clear in a new general strike. ${ }^{28}$ In Aragon, the main concern of the central and military authorities was the proximity to Catalonia and the fear of possible "contagion". The correspondence between the military captain general's office and the Ministry of War during the celebrations of 1 May 1891 had already contained references to the "agents of Catalonia". In 1905, this concern for crossborder transfer embraced the "revolutionary work" of almost a thousand Republican elements, in the face of which the general of the 5th Army Corps informed the Minister of War that he would try to stifle movement with "the few elements" at his disposal. A year later, the authorities again became suspicious that behind the canal workers' riots and strikes were "political issues and reckless propaganda". ${ }^{29}$ In the Portuguese region of the Alentejo, where dozens of rural workers' unions 
had arisen out of the strikes themselves, the National Federation of Rural Workers was created in August 1912, coinciding with a propaganda "tournée". ${ }^{30}$ One of the questions several workers were asked as part of the enquiries of the previously mentioned delegate commission regarded the exact nature of the relationship between the rural associations of the Évora district and the Lisbon workers.

A third important element was the co-occurrence of several conflicts. It is worth mentioning that, aside from the simultaneous strike episodes that took place over a short period of time in areas such as Spain's Badajoz province and Portugal's Alentejo region, there were other waves of protest occurring at the same time but making claims of a different nature. At the beginning of 1905, nearly a thousand workers from France and Catalonia went to the mayor of Tamarite de Litera and demanded to be allowed to work on the Canal of Aragon and Catalonia. At the same time, in neighbouring towns such as Benabarre or Albelda there were tax riots and workers rioting against the wealthy of the town assuming they were responsible for them, the workers, not being admitted to the canal works. In Ballobar, the Civil Guards of five adjacent posts were brought together to counter a collective attack on private property, a protest believed to be "aggravated by recent speeches". In April, approximately 500 workers on the Tamarite section threatened to go on strike. In Zaidín, several hundred people demonstrated in front of the town hall demanding work on the site. In August, the Tamarite workers rioted and members of the Civil Guard were once again concentrated in the vicinity. ${ }^{31}$

Faced with this state of things, both states redoubled their coercive capacities. In Spain, the number of Civil Guard staff and posts was increased, particularly after 1899 and between 1909 and 1910. In Portugal, the Republican Guard, formerly the Municipal Guard with jurisdiction in Lisbon and Porto, extended its range to the rest of the country, becoming the National Republican Guard. It was deployed for the first time in the Alentejo region. ${ }^{32}$ There are, however, several elements that show that there were important gaps in the apparent territorial coverage of the gendarmeries and armies of both countries, especially as the episodes of conflict multiplied. The correspondence between the Spanish Ministry of War and the regional commands of the Civil Guard and the general captains of the different military regions contains references to the excessive travelling times incurred by forces that were supposed to suppress or prevent the outbreak of conflicts. This was a major problem in areas where the railway infrastructure was scarce, such as in Extremadura, or where the railway service was highly unreliable, a frequent grievance in the east of the province of Huesca. During the 1902 strikes in the province of Badajoz, the correspondence between the forces and the central authorities pointed to the "remoteness" of some places (including some regional capitals, such as Olivenza), which brought with it some risk. As a result of simultaneous strikes and conflicts in various parts of the province, several Civil Guard commands warned that as the forces were concentrated in the capital there were none available for other areas, so requests were made to the Ministry of War to move several army units..$^{33}$ In Portugal, the Alentejo was the scene of this early deployment of the National Republican Guard. However, it was after, not before, 
the first wave of strikes in the summer of 1911 that the force was installed in the district of Évora, which saw the headquarters of the third battalion established there only in early November. It was not until September that there were posts in all the municipalities of the Alentejo. ${ }^{34}$ Army intervention continued to be necessary, but it was also fully mobilised alongside the National Republican Guard in the industrial zone south of Lisbon, including units based in districts of the Alentejo, such as the 5th cavalry, mobilised in August in the Setúbal area. ${ }^{35}$ To this must be added the frequent threats of alleged monarchical conspiracies and incursions into the north, which saw a very large number of troops mobilised between July and October 1911 and during the summer of 1912. It is certainly revealing that in the official inquiry into the strike episodes of May-July 1911 and January 1912 that opened in March 1912, the owners declared that "thanks to the deployment of the NRG" the character and especially the duration of the January strike had been markedly different. In November 1911, the civil government received repeated requests for a needed increase in the number of National Republican Guard posts. In February 1912, as several Alentejo deputies were expressing their joy at having "finally" had their properties guaranteed and defended, the civil governor of Évora warned the owners in the district of the need to reach agreements with the rural workers in the face of a probable new strike and the possibility that the resources they had at their disposal would not be sufficient to repress it. ${ }^{36}$

These insufficiencies could have two possible consequences: either the state's capacity to repress certain episodes of conflict would be reduced, or the lack of personnel would be particularly lethal where the conflict could not be properly managed. In 1902, a confidential note on public order from the Spanish Ministry of the Interior warned that in most cases of public disorder, a shortage of personnel meant that civilian governors were forced to entrust the military authorities with restoring calm, often resulting in "bloody scenes". ${ }^{37}$ This is indeed what happened in the city of Badajoz on 1 June 1902, when guards seriously injured dozens of strikers, killed a day labourer and arrested 130 people. That same afternoon, a state of war was declared in the city. ${ }^{38}$ At the beginning of March 1906 five day labourers were killed by the police in Fraga, in the Spanish province of Huesca. The stoppage at the Canal works close to the town led to protests and the calling of a general strike in the town. It was not until seven o'clock the next morning that a company from the infantry regiment arrived in the town. Three days after the event the force concentrated in the city numbered 150 men, while a company of 70 stayed for two months. ${ }^{39}$ In Évora, the military and the National Republican Guard violently evicted demonstrators who had gathered on 23 January for the new strike that had begun on 13 January. The result was dozens of arrests, one dead and several seriously injured. However, in this case it is more difficult to talk about a shortage of forces, since they arrived from all over the country in what seemed to be a real military occupation of the city. The strike had by then spread throughout the district of Évora and to some towns in the Beja, Santarém and Setúbal areas. In fact, it seemed to be an open choice to suppress the conflict manu militari: in the words of the governor, when the strike had been underway for 11 days, "I decided to attack it directly on the 24 th". ${ }^{40}$ 


\section{New repressive mechanisms parallel to the state: private action}

The need for repressive action in the more remote areas, something that needed not only to be done quickly but also to be maintained, spurred the involvement of the private sphere. The shortage of forces, the distance from the major cities, the empowerment of workers ensuing from their organisation and militancy, and the proliferation of simultaneous protest episodes meant that state repression was often not enough. Private citizens were therefore pushed into taking an active part in repressive tasks. The organisational boom in the workforce had its counterpart in the acceleration of the processes by which owners and employers formed associations. These platforms, however, sought not only to become economic lobbies, but also to increase their management capacities on various fronts, including policing. ${ }^{41}$ This section outlines five strategies of private sphere intervention in the management of public order in parallel with - and often with the acquiescence of - state institutions.

The first strategy for dealing with the workers' increasing mobilisation in the context of a weak state presence was negotiation. The records of the Instituto de Reformas Sociales contain accounts of many episodes of strikes in Spain that were settled by "direct management between employers and workers". Sometimes this negotiation took the form of opening subscriptions and distributing coupons, as was done on many occasions in 1906 in the villages in the Canal of Aragon and Catalonia construction area in response to concerns about the increase in episodes of protest. However, this failed to meet the workers' aspirations. On other occasions, the productive calendar or mediation by the authorities were the main reasons for committing to a negotiated solution. This is what occurred at the beginning of June 1911 in Évora, where a meeting was held between employers and workers at which the latter greatly outnumbered the former. The agreements reached at this meeting represented a partial victory for the rural workers, but they were later ignored by the employers, which led to a second wave of strikes. Appearing before the commission delegated to clarify the facts, several owners declared that they had signed the agreement out of fear of reprisals and that at the time they would have signed anything the strikers wanted. Several of them also added that the forces of law and order had not been present at the meeting. ${ }^{42}$

The second strategy was the systematic use of law enforcement for private purposes. The difficulties that both gendarmeries had in establishing a presence throughout the entire territory were solved in innumerable cases with the active participation of owners, patrons and private companies. Companies such as the Energía Eléctrica de Cataluña in Capdella or the Empresa Catalana de Gas y Electricidad in Seira rented buildings to convert them into barracks for the Civil Guard in view of the arrival of substantial numbers of workers once work began on the plants in $1912 .{ }^{43}$ In both countries, the central institutions warned of the abuse this practice constituted. In 1901 the Spanish Ministry of the Interior drew attention to the frequency with which the Civil Guard were concentrated in provincial capitals and other major towns "without a really justified reason". A year later, a letter sent to all the governors mentioned that the municipalities and especially 
individuals were making "excessive" requests. The Portuguese Ministry of War had already noted in 1887 the "repeated and excessive requests for armed force". ${ }^{4}$ However, it is revealing that over time these requests did not diminish, but the central authorities' discouragements did, and ultimately they chose instead to approve of this private subsidy. In a circular to the district administrators in November 1911, the civil governor of Évora made it clear that it would be impossible to increase local allocations of the National Republican Guard. Aware that many employers had already tried to remedy the situation through their own means, he legally established that they would be responsible for the costs of the additional places. The employers' union of each locality was to make a request to the Ministry of the Interior to this effect. The need was "urgent", according to the governor. ${ }^{45}$ This was not, however, a radically new practice: as early as 1908, in the last years of the monarchy and coinciding with a period of marked social agitation due to the concentration of numerous groups of workers protesting against unemployment, some "citizens' commissions" offered to pay the salaries of civil police, who were then used as private night watchmen in different towns. ${ }^{46}$

Closely related to this last strategy is the third: delegation of law enforcement powers by the government to groups of individuals. In Spain, the "Rural Police Law" allowed landowners' organisations to become Farmers' Associations (Comunidades de Labradores) or Rural Police Unions. Under this law, passed in July 1898 , the public order powers previously granted to the municipality were transferred to local landowners. The vast province of Badajoz would have the largest number of these associations and police unions. ${ }^{47}$ In 1902, after the second strike of rural workers in several areas of the province of Badajoz and at a time when there were signs of a stable workers' association, a confidential letter from the Ministry of the Interior to the civil governor of the province stressed the need for more preventive work, which was to be complemented by the active participation of the owners: "Even more important will be to bring to the minds of individuals the essential need to combine their efforts and proceed to protect their interests by forming associations in the localities", measures considered "extremely necessary" in the broad terms of the province's municipalities. ${ }^{48}$ Although the Rural Police Law was intended to be applied particularly in areas where the latifundia system was prevalent, other localities operating under different systems would form their own "farmer's associations". This was the case in some of the towns involved in the Canal of Aragon and Catalonia protests, such as Barbastro, where one of these associations had already been created in 1904, very early compared with the others that would be established throughout the country, including several in the province of Badajoz. Thereafter, questions of public order disappeared completely from the municipal records. ${ }^{49}$ Although the construction of the Canal of Aragon and Catalonia had passed into state hands in 1896, the local elites maintained a high degree of involvement in the works, mainly because they were the ones who ended up building the secondary sections of the canal. From 1894, a corps of labourer-watchmen (peones-vigilantes) were engaged on the work, but in the years of greatest strike agitation, an organisation was set up to defend the interests of the Canal. That same year saw towns or 
sections of the Canal beginning to form Associations of Irrigators (Comunidades de Regantes) of the canal area. Each association had a steering board composed of owners, who had police jurisdiction over their area, and a first instance jury (as did the Farmer's Associations). ${ }^{50}$ In Portugal, however, alongside the aforementioned establishment of commissions for the private use of the police force, there appears to have been greater recourse to individual legitimate defence. Since the beginning of the republic, there had been a very noticeable increase in the number of arms licences granted to owners and traders. This was because of, among other things, the greater territorial deployment of the state and greater control over the circulation of previously unlicensed weapons. However, it also confirms an earlier trend, already noticeable from 1908 in the district of Évora. Even then, the large number of weapons, both shotguns and revolvers, declared as weapons "for self-defence" (which included defence of person and property) was noteworthy. ${ }^{51}$

Along with the delegation, a fourth one was the permissiveness in the constitution of private police. Significantly, this was the strategy adopted by some of the companies established mainly through foreign initiative and with foreign capital, particularly those involved in mining. Subordination to foreign capital, together with the desire to maintain good relations with these companies, ended up generating strong relationships of dependence and the ceding of important spaces of sovereignty to them. ${ }^{52}$ This was also evident in the area of policing. Private police forces paid by company directors had become widespread since the beginning of the twentieth century in the large mines of the southern Alentejo region of Portugal owned by firms such as the British Mason \& Barry or the Belgian Société Anonyme Belge des Mines de Aljustrel. The miners of the Baixo Alentejo staged several strikes in 1879, 1905, 1907 and 1912. The 1912 strike came after the constitution of the mining union and was part of the cycle of protests that took place throughout the country following the events in Évora. The companies' private police were actively involved in the repression of these strikes. ${ }^{53}$ The same was true on the other side of the border, in the mining areas around the basins of the southern Alentejo. The Rio Tinto Company Limited, the British firm that had won the contract for the deposits in the Riotinto mining basin in the Spanish province of Huelva, Andalusia, also had its own police force, the so-called guardiña. The members of these corps were tasked with surveillance of both the facilities and the workers and exercised the functions of a kind of political police. Surveillance was reinforced during the strike preparations, when the numbers of guardiña were increased or new positions were created within the body, as happened in 1913 in Riotinto with the creation of the position of "house guard". ${ }^{4}$ However, the large number of workers concentrated in these districts meant that these forces were insufficient to maintain public order in the event of open conflict, so the assistance of the state's repressive forces continued to be necessary. Fearing a strike, requests continued to made for units of infantry and cavalry. In Riotinto, the massacre that had taken place during a first strike in 1888 was at the hands of the private police forces, the Civil Guard and the army and was one of the bloodiest episodes of the period of Spanish Restoration. There was, furthermore, close cooperation between the company's police and the Civil Guard forces. ${ }^{55}$ 
The final strategy is of "civic defence of order". That the emergence and proliferation of patriotic leagues, civilian shooting groups and militias and the increases in their membership coincided with the main episodes of strike and social conflict is indicative. This was the case in the province of Badajoz, where the National Shooting Federation (Tiro Nacional), the delegation of the civil shooting federation, was especially active from $1902 .{ }^{56}$ In 1911 , the members of some municipal governing bodies of towns in the Portuguese Alentejo region, such as Reguengos de Monsaraz and Estremoz, were keen to build shootings ranges and join the socalled National Shooting Crusade (Cruzada Tiro Nacional). ${ }^{57}$ The so-called battalions of Republican volunteers were involved in the strike called by the railway workers of the Companhia dos Caminhos de Ferro do Sul e Sueste that took place in January 1911 with demonstrations in several municipalities of the Alentejo. The Republican volunteers had emerged in the heat of the civic mobilisation that accompanied the revolution and were, according to the governor of Lisbon, the "best assistant for maintaining order" given a police force that was "not sufficiently republicanised". ${ }^{58}$ The members of these battalions replaced striking workers and were involved in strike repression, which included arresting workers from several Alentejo towns, conduct that was later imitated in the industrial zone south of Lisbon and in the capital itself. That same month, the battalions were also instrumental in extinguishing a rural workers' strike in Estremoz. ${ }^{59}$ In mid-August 1911, the governor of Évora in a letter to the commander of the fourth military division referred to the existence of "non-official" battalions. The word "legal" in the draft version was changed to "official" in the final version. ${ }^{60}$ Later on, in a formal declaration to the government commission, a volunteer proudly pointed out that even before the establishment of the Republic, he had been a member of the Carbonária secret society. During the summer strikes he was in charge of surveillance of the rural workers and anyone else who was in the movement. He added that this type of "careful vigilance" was exercised "continuously and rigorously" by militant Republicans. A little later, in 1913, in the era of the government of Republican Democratic Party leader, Afonso Costa, the group Formiga Branca (the termite) was created and was supported and promoted by the institutions themselves, particularly the civil government of Lisbon. Its members were granted special police status and were authorised to carry weapons; the police could not interfere with their activities. In January 1914, alongside the National Republican Guard, they were involved in breaking the railwaymen's strike in the capital. Their role seems to have been to restrain the advance and extension of the protest, since they seem to have been involved in repressive activities in other parts of the country, signs of which could be seen in the south of Alentejo during the mining protests of 1915 and in Évora, where they allegedly supported the Republican National Guard in suppressing a demonstration and imprisoning more than 30 trade unionists in January $1916 .{ }^{61}$

\section{Conclusions}

The evidence presented here show a convergence of interests and a confluence of strategies on the part of the state, the employers and the wealthy classes of both 
countries regarding the maintenance of public order in the context of a gradual consolidation of modern capitalism. In both Spain and Portugal, we see a significant change in the methods for dealing with the rise of strikes, often caused by difficulties in implementing this capitalist modernisation. All the same, institutional permissiveness with regard to the creation of parallel forces, or even the delegation of these powers to private entities, cannot be attributed solely to a certain inability on the part of the state to cover the territory effectively in situations of conflict. In both cases, it was within the very framework of the process of strengthening the state and increasing its repressive capacity that these efforts were redoubled. On the other hand, there is no doubt that these methods reached a greater degree of complexity in regard to activities where the weight of the private sector was stronger. However, at no time did the public institutions, owners and those companies with national or foreign capital abandon the use of public force as the main element of both repression and deterrence. One of the reasons for this was undoubtedly the clearly military nature of repression exercised by the gendarmeries in the two countries, the Spanish Civil Guard and the Portuguese National Republican Guard, and by the army, which was particularly aggressive.

Nonetheless, in the case of both Spain and Portugal, the state's repressive actions were often reinforced by the active participation of the private sector. It is useful to consider this coalition as a convenient solution to the problem of covering a rural periphery in a gradual process of change. This did not exclude a certain fear that control over the maintenance of public order would be dispersed. However, this suspicion was mitigated in both countries by a confidence in the convergence of the interests of central institutions, elites and the bourgeoisie. How this process evolved depended not only on the economic situation and cycles of protest, but also on the differing political actions of both governments. Although it is difficult to establish a clear line of development or to talk about real planning in this combination of forces, we can draw up an approximate chronology covering these two and a half decades. In this, we can distinguish three periods delineated by distinct political crises and regime changes, and clear changes in the patterns of social protest or even significant transformations in repressive attitudes and strategies.

The first period covers the last decade of the nineteenth century and was marked by a notable increase in social conflicts and strikes, exceptional measures in terms of public order and the beginning of the mobilisation of the private sector. Along with this was the end-of-the-century crisis and a timid modernisation, a process that proved to have high social costs. In addition, the political crises following colonial losses by both countries resulted in a toughening of political-social measures and a certain abandonment of the maintenance of public order outside the major regional capitals. Militarisation was very evident in Spain, especially in the wake of the colonial crisis, while in Portugal exceptional measures were eased after 1897, although the army remained the main police force. The rise of property-owners' associations led to requests from individuals for greater powers in upholding public order, a dynamic that was accompanied by an increase in the use of available forces for private purposes. These years were also marked by an 
increase in patriotic leagues and a strengthening of the discourse on civic defence of the fatherland and order.

The second period covers the first decade of the twentieth century and was characterised by a growing fear of social overflow, the entrenchment of tough policies and the state sanction of private activities. The turn-of-the century years were particularly marked by the threat of a general strike in Spain and by a strike boom in Portugal. The aforementioned dynamics of protest were reinforced, and this coincided with a greater structuring of the labour movement and the republican alternatives. The attempted state intervention in social matters and the timid democratic opening were combined with an iron-fisted policy when it came to managing the rise of protest. While in Portugal this softened after the 1908 regicide, in Spain the process was particularly marked by the military's desire for autonomy and became more starkly evident from 1909. Moreover, with this policy repression had a lower political cost because of the radicalisation of sectors of the elite and the bourgeoisie. Aside from this, the trend towards private control of public order mechanisms continued, particularly in the rural peripheries, and was now backed by state legislation that sanctioned this private violence on a delegated basis. In addition, the use of private police increased in some industrial sectors, particularly by foreign-owned companies.

The third period covers the second decade of the twentieth century up to the beginning of the First World War and was marked by limitations to the process of democratic opening, the definitive consolidation of militarisation and the emergence of a new vigilantism. At the same time the rise of workers' associations led to a further increase in the number of strikes. However, the implementation of arbitration measures was combined with a harsh repressive policy in both countries, resulting in definitive consolidation of the militarisation of public order. In the case of Portugal, the new republican regime's quest for stability together with the conversion of the elites into new political clients was a setback for the very openness these measures announced. In contrast, there was a gradual strengthening of the model of citizen surveillance in the form of volunteer battalions and citizens' militias, which, in the midst of a formal democratisation process, was occasionally encouraged or even outrightly permitted by the institutions, and therefore circumvented certain legal constraints. At that time, in Spain, citizen militias would occasionally take to the streets in the role of anti-worker militias, as the Somatén did in Catalonia; this was a model that would spread to the latifundia, especially in the interwar years (and very particularly during the so-called Bolshevik Triennium, 1918-20). Some scattered youth militias also began to settle in provincial capitals, such as Badajoz and Huesca, leading to some incidents in the latter city. ${ }^{62}$

The deployment of such a plurality of practices was part of a dynamic in which the centre-periphery dialogue was a major component. This partial convergence of interests between the state, the upper-middle classes and other institutions, such as the army and the church, in relation to socio-labour conflicts would lead to new political cultures becoming more clearly defined and the pre-configuration of elements that in both Spain and Portugal would contribute to the future consolidation of authoritarian regimes. 


\section{Notes}

* Research for this article received funding from the European Research Council (ERC) under the European Union's Horizon 2020 Research and Innovation program (G.A. 677199 - ERC-StG2015 "The Dark Side of the Belle Époque. Political Violence and Armed Associations in Europe before the First World War").

1 "La huelga," La Época, October 28, 1903, 1.

2 In Spain, during the period 1905-14 there was an average of 211 strikes per year, being higher or much higher in the years 1910-14, with a peak in 1911 (311 strikes). In Portugal where official statistics at the time are almost non-existent, the data indicate an average of 65 strikes per year for the period 1887-1908. From 1909 this record is much higher, reaching 535 strikes in 1910 and 419 strikes in 1911. Always bear in mind that the available data are fragmentary. See the reports of the Institute of Social Reforms for this period, published between 1906 and 1917 and available online in "Repositorio Documental," Ministerio de Trabajo, Migraciones y Seguridad Social. Gobierno de España, and also Javier Silvestre, "Los determinantes de la protesta obrera en España 1905-1935: ciclo económico, marco político y organización sindical," Revista de Historia Industrial, no. 24 (2003): 75-76. For the case of Portugal, see José Tengarrinha, "As greves em Portugal: uma perspectiva histórica do seculo XVIII a 1920," Análise Social 17, no. 67-68 (1981).

3 This was particularly true in Spain, as noted in Manuel Pérez Ledesma, Estabilidad y conflicto social. España, de los iberos al 14-D (Madrid: Nerea, 1990), 188. However police and vigilante violence reached its peak in Portugal from 1911 onwards and particularly from 1913, to the point that PM Afonso Costa was nicknamed the "racha sindicalistas" (unionist-breaker).

4 According to the aforementioned sources, in Spain strikes in Madrid and Barcelona represented between 30 and 50 per cent of the total between 1905 and 1914, being more than half of them in the years 1909 and 1910. In Portugal, of the 725 strikes of which we have this information between 1875-1900, 510 (70 per cent) are concentrated in Lisbon and Porto. During the turn of the century secondary industrial centres such as Setúbal and Faro gained importance, followed by other Portuguese districts in the twentieth century.

5 In Instituto de Reformas Sociales, Memoria Estadística de las huelgas (1904-1905) (Madrid: Imprenta de la Sucesora de M. Minuesa de los Ríos, 1906).

6 Tengarrinha, "As greves," 587.

7 Paulo Eduardo Guimarães, "O motim e a greve," in Indústria e conflito no meio rural: Os mineiros alentejanos (1858-1938) (Évora: Publicações do Cidehus, 2001).

8 A synthetic overview in Carlos Forcadell Álvarez, "El sector agrario aragonés en la crisis de finales del siglo XIX," in Historia de Aragón (Zaragoza: Institución Fernando el Católico, 1996).

9 The alleged socio-economic stagnation of these years in both Extremadura and the Alentejo has been qualified in some works. See Martin Baumeister, Campesinos sin tierra. Supervivencia y resistencia en Extremadura (1880-1923) (Madrid: Ministerio de Agricultura, 1997), 42-62; Helder Adegar Fonseca, "Élites agrárias e crescimento económico na periferia portuguesa do século XIX: o exemplo do Alentejo na era liberal," Análise Social 33, no. 146-147 (1998): 497-98; Paulo Guimarães, "O comportamento estratégico das elites económicas alentejanas face à actividade industrial: algumas evidências a partir da região de Évora (1880-1926)," Ayer no. 48 (2002).

10 For Spain see Demetrio Castro Alfín, "Agitación y orden en la Restauración. ¿Fin de ciclo revolucionario?" Historia Social, no. 5 (1989): 37-49, and Eduardo González Calleja, "La política de orden público en la Restauración," Espacio, tiempo y forma, no. 20 (2008): 93-127. For the case of Portugal, see Diego Palacios Cerezales, "Técnica, política e o dilema da orden pública no Portugal contemporáneo (1851-1974), " in Lei e Ordem. Justiça Penal, Criminalidade e Polícia. Séculos XIX-XX, ed. Pedro Tavares de 
Almeida and Tiago Pires Marques (Lisbon: Livros Horizonte, 2006), 147-72, and from the same author "Estado, régimen y orden público en el Portugal contemporáneo" $(\mathrm{PhD}$ diss., Universidad Complutense de Madrid, 2008).

11 Eduardo González Calleja, La razón de la fuerza. Orden público, subversión y violencia política en la España de la Restauración (1875-1917) (Madrid: Consejo Superior de Investigaciones Científicas, 1998). For Portugal see the aforementioned works by Diego Palacios Cerezales and Gonçalo Rocha Gonçalves, "O aparelho policial e a construção do Estado em Portugal, c. 1870-1900,” Análise Social, no. 216 (2015): 471-93.

12 On this, see Matteo Millan, "Introduction: Strikebreaking During Europe's Belle Époque," European History Quarterly 49, no. 4 (2019): 553-69.

13 I deliberately use the term "double periphery" despite the valuable critical contributions that have been made to the concepts of "periphery" and "centre". See, for example, Anne Radeff, "Centres et périphéries ou centralités et décentralités?" in Per vie di terra. Movimenti di uomini e di cose nelle società di antico regime (Milan: Franco Angeli, 2007), and Christian De Vito, "History without Scale: The Micro-Spatial Perspective," Past and Present 242 (2019). By using it I intend to point out not only the inclusion of Spain and Portugal in an area where the development of capitalist modernization was particularly late and costly in social and political terms, but also to note that this worked as a self-representation as well: in both countries there was a widespread idea about being "peripheral", particularly in some areas. On the one hand, in both cases there was a recurrent discourse on the need for a "Europeanization" of the country at all levels; on the other hand, there was a repeated criticism of those who felt excluded from decision-making spaces, both socially and territorially.

14 Quoted in Victor Lucea Ayala, El pueblo en movimiento. La protesta socialen Aragón (1885-1917) (Zaragoza: Prensas Universitarias de Zaragoza, 2009), 100.

15 See Palacios, "Estado, regimen," 3. The numbers of the Civil Guard force in Spain in González Calleja, La razón, 47.

16 Diego Palacios Cerezales, "Weak State and Civic Culture in Liberal Portugal (18511926)," in The Making of Modern Portugal, ed. Luís Trindade (Newcastle: Cambridge Scholars Publishing, 2013). On the extension of the gendarmerie model during the nineteenth century throughout Europe, see Clive Emsley, Gendarmeries and the State in Nineteenth-Century Europe (Oxford: Oxford University Press, 1999).

17 The tentacular deployment of the Spanish Civil Guard responded to the same logic of the dam, becoming, together with the army, a real force of "military occupation of the territory" as stated in González Calleja, La Razón, 51. In Portugal the first territorial deployment of the National Republican Guard in 1911 was in the Alentejo region, the epicentre of the strike movement outside the capital during the first moments of the Republic. When some deputies from the north of the country, which was being the main focus of monarchical incursions, complained of their lack of protection, they were told that they instead had to wait, since there "strikes were not so frequent", quoted in Palacios, "Estado, regimen", 338.

18 El Liberal, March 20, 1897, 1; “La crisis obrera," El Imparcial, April 20, 1897, 1; “El Canal de Tamarite," La Correspondencia de España, April 28, 1897, 1.

19 Archivo General Militar de Madrid (hereafter, AGMM), "Huelga en en Canal de Aragón," sig. 5854.61; "Huelga de obreros del canal de Aragón y Cataluña," sig. 5855.51.

20 Fernando Sánchez Marroyo, "Los Congresos Obreros de Torre de Miguel Sesmero. El surgimiento del movimiento asociativo de los trabajadores rurales en Extremadura a comienzos del siglo XX," in Congresos obreros en Torre de Miguel Sesmero, ed. Francisco Joaquín Pérez González (Badajoz: Diputación Provincial de Badajoz, 2003); AGMM, "Huelgas agrícolas en la provincia de Badajoz en 1902," sig. 5855.16.

21 Jesús Ángel Redondo Cardeñoso, "Democracia y conflictos rurales en Portugal: la instauración de la I República en el Alentejo (1908-1912)," in La Historia, lost in translation? Actas del XIII Congreso de la Asociación de Historia Contemporánea, ed. 
Damían A. González Madrid et al. (Cuenca: Ediciones de la Universidad de Castilla-La Mancha, 2017), 1327. See also José Pacheco Pereira, Conflictos sociais nos campos do sul de Portugal (Lisbon: Publicações Europa-América, 1982).

22 Arquivo do Ministério do Interior - Arquivo Nacional Torre do Tombo (AMI-ANTT), Mç. 38, no. 141. Letter from the civil governor to the Ministry of Interior January 27, 1912.

23 Notícias de Évora, June 2, 1911 and June 6, 1911; O Eco de Reguengos, June 8, 1911.

24 Martí Boneta Carrera, "Las construcciones hidroeléctricas de la Vall Fosca, de Energía Eléctrica de Cataluña (1911-1940)," in Capitalismo e historia de la electrificación, 1890-1930: capital, técnica y organización del negocio eléctrico en España y México, ed. Horacio Capel Sáez and Vicente Casals Costa (Barcelona: Serbal, 2013), 109-20.

25 "Movimiento obrero. La huelga de albañiles de 'La Canadiense'," Heraldo de Aragón, December 12, 1913, 2.

26 "Huelga en el Run," Diario de Huesca, May 17, 1914, 1.

27 Palacios, "Estado, régimen," 349-50; Álvaro Arranja, A República e os operários. A Greve Geral de 1912 na imprensa da época (Setúbal: Centro de Estudos Bocageanos, 2017).

28 Sánchez Marroyo, "Los Congresos," 20.

29 Lucea, El pueblo, 445. During the interwar years this area began to stand out, together with Zaragoza, because of the rooting of anarcho-syndicalism.

30 António Ventura, O sindicalismo no Alentejo. A “tournée" de propaganda de 1912 (Lisbon: Seara Nova, 1977), 32.

31 Lucea, El Pueblo, 182-84.

32 González Calleja, La razón, 47; Palacios, "Estado, régimen,” 337.

33 AGMM, "Huelgas Agrícolas 1902 Badajoz," sig. 5855.16.

34 Arquivo Histórico da Guarda Nacional Republicana, GNR 3rd Battalion Order Book. From 3 July 1911 to 11 November 1912; Palacios, "Estado, régimen," 336.

35 Arquivo Histórico Militar, $1^{\mathrm{a}}$ Divisão, Secção 34, Cx. 1, "1 ${ }^{\mathrm{a}}$ República (1 ${ }^{\mathrm{a}}$ fase). Revoltas e incursoes monárquicas (1910-1914)". Letter from the command of the 3rd Military Division to the Ministry of War, 20 July 1911.

36 AMI-ANTT, Mç. 38, no. 141. Statements by owners and circular letter from the civil governor of 12 February 1912. The satisfaction expressed by several Alentejo deputies in Palacios, "Estado, régimen," 336.

37 Archivo Histórico Nacional (AHN), Ministerio de Gobernación serie A, Legajo 44(3), Expediente 22. Confidential note on the maintenance of public order (1902).

38 The arrests in Archivo General Militar de Segovia (AGMSg), "Recompensas. Relativo a Orden Público," Sección 2a, División 12, legajo 152.

39 AGMM, "Motín en Fraga (Huesca) en 1906," sig. 5868.1.

40 AMI-ANTT, Mç. 38, no. 141. Letter from the civil governor of Évora to the Minister of the Interior, 27 January 1912.

41 On the activities of these employers' organisations beyond their role as economic lobbyists and in the field of violent organisational responses to the action and demands of trade unions and working-class parties, see the comparative study by Matteo Millan, "The Shadows of Social Fear: Emotions, Mentalities and Practices of the Propertied Classes in Italy, Spain and France (1900-1914)," Journal of Social History 50, no. 2 (2016): 336-61.

42 AMI-ANTT, Mç. 38, no. 141.

43 José Antonio Cubero y Carlos Bravo, La aventura hidroeléctrica en el Valle del Ésera 1912-2012 (Huesca: Diputación Provincial de Huesca, 2012); Boneta, "Las construcciones," 118.

44 AHN, Serie A, Leg. 39, Exp. 1. Arquivo Distrital de Évora (ADE), Fundo Governo Civil, H/F Policia e criminalidade, Cx. 266. Letter from the Ministry of the Interior to civil governors, dated 25 August 1887. 
45 ADE, Fundo Governo Civil, E/C Instrumentos de recuperação de correspondência, Cx. 270, pç. 153. Governor's circular of November 1911.

46 ADE, Fundo Governo Civil, H/F Policia e criminalidade, Cx. 144 "Guarda Nocturna e Policia Rural".

47 The law is critically discussed in José Llagaria Ballester, Policía rural (ley de julio de 1898). Comunidades de Labradores (Valencia: García y Suay, 1903).

48 AHN, Serie A, Leg. 5, Exp. 1. Ministry of the Interior. Under-Secretary of Public Order. Confidential report of April 1902.

49 Archivo Municipal de Barbastro, A472-04, Libro de Actas 1904, 63. For the dates of the creation of the associations, a guide in a late work: Censo estadístico de Sindicatos Agrícolas y Comunidades de Labradores, Ministerio de Agricultura, 1934, 397-402.

50 La Época, October 20, 1902, 2; El Liberal, October 24, 1904, 1. More information in Antonio Ibarz Ibarz, El Canal d'Aragó $i$ Catalunya: cent anys d'esperança i de progrés (Huesca: Institut d'Estudis del Baix Cinca, 2005), 73, 77, 96. Brief information available about the watchmen's corps, in Archivo Histórico Provincial de Huesca (AHPH), Fondo de Obras Públicas, OP. 381.

51 ADE, Fundo Governo Civil, H/C Licenciamentos, CX-7.

52 In the case of Portugal, there was another aspiration: the acceptance and recognition of the new regime by foreign powers. Interestingly, in other countries, other cases of private companies under purely capitalist management show this same relationship between a strong sovereignty of private capital, strong links of dependence between the workers and the company and the creation of private police forces aimed at the harsh repression of the labour movement, particularly in cases of strike. See for example Matteo Millan, "'The Public Force of the Private State' - Strikebreaking and Visions of Subversion in Liberal Italy (1880s to 1914)," European History Quarterly 9, no. 4 (2019): 625-49. In the same issue, and in relation to private mining companies in the Ruhr area and the activities of the Zechenwehren auxiliary corps, see Amerigo Caruso, "Joining Forces against 'Strike Terrorism': The Public-Private Interplay in Policing Strikes in Imperial Germany, 1890-1914," European History Quarterly 49, no. 4 (2019): 597-624.

53 Paulo Guimarães, "Indústria e conflito no meio rural," in Indústria e conflito no meio rural: Os mineiros alentejanos (1858-1938) (Évora: Publicações do Cidehus, 2001).

54 José Juan De Paz Sánchez, "Félix Lunar y el movimiento obrero en Huelva (19081920)," in A cielo abierto. De Riotinto a Norteamérica, ed. Félix Lunar (México: Imprenta Manuel León Sánchez, 1956), 64.

55 Also noted in Miguel Collado Aguilar, "La Guerra Civil y la represión franquista en la Cuenca Minera de Riotinto" (PhD diss., Universidad de Huelva, 2018), 22. Collado Aguilar also points out that the railway service during the 1913 strike was maintained for ten days by the guardiña (297). On the 1888 massacre there are very different estimates of the number of deaths. In a recent study Gérard Chastagnaret puts the figure at 200 , taking into account concealments of dead workers, the subsequent deaths of those seriously injured and the deaths of unregistered migrant workers, in Gérard Chastagnaret, Humos y sangre. Protestas en la cuenca de las piritas y masacre de Riotinto (1877-1890) (Alacant: Publicacions de la Universitat d'Alacant, 2017). However, this figure is much higher than that stated by other authors and even than the figures offered by militants of workers' organisations, for example the socialist Juan José Morato, who based on the workers' press noted 30 deaths and 150 injured; in Juan José Morato, Pablo Iglesias. Educador de muchedumbres (Barcelona: Ariel, 1977 [1931]). It seems plausible to contemplate the figures provided by David Avery, confirmed by subsequent local investigations and an internal report by the company itself, according to which the deaths could have reached 40 (with the authors pointing out that there could have been many more): see David Avery, Not on Queen Victoria's Birthday: The Story of the Rio Tinto Mines (London: Collins, 1974), and María Dolores Ferrero Blanco, "Los sucesos 
de Riotinto de 1888 según los directores de la Rio Tinto Company Limited," Revista de Historia Industrial, no. 14 (1998).

56 AGMSg, "Campos de instrucción y tiro 1883-1915," Sección 2a , División 8a legajo 193. Also in the correspondence with the spaces of sociability of the owner class, in Archivo de la Real Sociedad Económica de Amigos del País de Badajoz, Caja 4, 1B.1.6.

57 Arquivo Municipal de Reguengos de Monsaraz, C-1/001/00025 [1908-1911], "Registo da correspondencia official espedida a differentes auctoridades, funcionarios, corporações, etc., 81B. Letter from the Municipal Chamber to the president of the "Cruzada Tiro Nacional," ADE, Fundo Governo Civil, E/C Instrumentos de recuperação de correspondencia, cx. 270, pç. 44. From a communication by the civil government of Évora to the municipal chamber of Estremoz on 27 October 271911.

58 Palacios, "Estado, régimen," 354.

59 Vasco Pulido Valente, "A República e as classes trabalhadoras (Outubro de 1910Agosto de 1911)," Análise Social 9, no. 34 (1972): 311-12.

60 ADE, Fundo Governo Civil, E/C Instrumentos de recuperação de correspondencia, Cx. 270 , pç. 153. Letter from the civilian governor of Évora to the commander of the 4th military division, 19 August 1911.

61 Diário do Senado da República of January 19, 1 and 8 May 1914, quoted in Palacios, "Estado, régimen," 353-55. A Questao Social, 30 January 1916, quoted in Paulo Guimarães, "Os mineiros na República: aspirações e derrotas," in Indústria e conflito no meio rural: Os mineiros alentejanos (1858-1938) (Évora: Publicações do Cidehus, 2001).

62 AHPH, Provincial Court of Huesca. Book of criminal sentences 1913, J2575. 